\title{
決定関係の導入による概念設計知識の表現と獲得 ${ }^{\dagger}$
}

\author{
川上浩 司*•片 井 修**・椹 木 哲 夫** \\ 小西忠 孝*・岩 井 壮 介***
Knowledge Representation and Acquisition for Conceptual Design by Determination Relations \\ Hiroshi KawaKami*, Osamu Katai**, Testuo Sawaragi**, \\ Tadataka KONISHI* and Sosuke IWAI ${ }^{* * *}$
}

\begin{abstract}
This paper proposes methods of knowledge representation and acquisition for conceptual design of physical systems by introducing the notion of determination rules. From Value Engineering perspectives, physical systems are interpreted by their functions, structural attributes, and the means-ends relations relating with them, i.e., functional compositions, physical causal laws, and structural compositions. These knowledge are used as the initial domain theories of EBG (Explanation-Based Generalization), then they are refined through compilation. Through examining the fundamental structures of determination rules they are then introduced to the domain theory of EBG. They reflect relations among functions structures and their causes/effects by which various types of empirical design knowledge can be reprsented. Using determination rules as the domain theory of EBG, they are once instantiated for an exampler object, and then generalized by identity elimination. Through these processes, they are reformed into. efficient and rationalized design knowledge utilizable for systematic design processes: This method is implemented to a system in a logic programming environment.
\end{abstract}

Key Words : EBG, VE, determination rule, knowledge acquisition, CAD

\section{1.はじめに}

物理設計物の概念設計レベルを対象とした設計知識の 表現法およびその獲得手法を提案する。まず，VE(価値 工学：Value Engineering) ${ }^{1)}$ の視点から設計行為を捉え ることによって,設計物の表現に必要となる知識を機能・ 物理法則・構造それぞれに関する知識から組織化すると ともに，厳密なルールよりもコーディングが容易である 決定関係を導入した設計知識表現について検討を行う。 決定関係の論理的表現である決定則 ${ }^{2), 3)}$ を導入し, 決定 則のもつ情報構造を対象分割の概念を用いて明らかにす る.さらに,これらの知識を獲得するために, EBG

†第 17 回知能システムシンポジウムで発表(1993・3)

* 岡山大学工学部 岡山市津島中 3-1-1

** 京都大学工学部 京都市左京区吉田本町

*** 名城大学理工学部 名古屋市天白区塩釜口 1-501

* Faculty of Engineering, Okayama University, Okayama

** Faculty of Engineering, Kyoto University, Kyoto

*** Faculty of Science and Technology, Meijo University, Nagoya

(Received September 20, 1993)

(Revised March 24, 1994)
(Explanation-Based Generalization) 法4) の領域知識に メ夕知識として，決定則を導入した方法を考える。その 結果, 決定則が事例記述に呼応して特殊化され, 合理性・ 効果性の付与された設計知識が獲得される.

\section{2. 物理設計物を表現する設計知識}

\section{1 概念設計のための設計物表現}

新たなアイデアの付加，根本的な改良および新規設計 などは,たとえ結果が表面的には材質・形状などの構造的 な変更や付加という形で現れるとしても，背後にある機 能に注目した情報処理によって実現される。

このような機能に注目した処理は設計プロセス上は概 念設計と呼ばれ, 基本設計・詳細設計などの下流工程にお いて具現化される設計案を生成する重要な部分である.

設計の下流工程においては設計パラメー夕最適化の 種々の手法が提案され, 計算機支援が実現されているが, より大きな効果が期待される概念設計レベルについて は，系統的な方法はいまだ確立されていない。

VE の分野では，機能に注目した設計事例の解析およ び改善案導出をシステマティックに行う機能分析法 
(Functiona1 Analysis)が実践されている11。これは，分 析対象物の目標(基本機能達成)にどのような手段(副機 能)が用いられているか(機能構成),それら機能がどの部 分により実現されているか(機能と構造の結びつき)を機 能系統図と呼ばれるダイヤグラムで表現し，これに基づ いて新機能追加，製造コスト低減などの設計改善を検討 する手法である。

これによると，設計物は「基本機能(目標：G)を達成す る手段として一連の副機能 $(F)$ が選択され，これらの機 能を達成する手段として選択された構造属性(S)をもつ 実体」であると解秎することができる。

これらの機能と構造を関係づけるためには, ある機能 とそれを達成する構造条件とを媒介し, 機能の追加や変 更とそれに伴う構造的追加や変更とを対応させる知識を 設定する必要がある。物理法則や物理現象に支配された 構造物を作る機械設計を対象とする場合，これらを媒介 する知識として物理因果法則が重要なものと考えられる。

以上の考察汃ら，設計物を，機能・構造属性を表わすラ ベルと, 目標一手段の組という統一的な形式をもつ,つぎ の三つの知識によって表現する。すなわち，機能とそれ を達成する副機能に関する知識(Fig. 1(a)), 機能とそ れを達成する構造属性を媒介する物理因果法則(Fig. 1 (b))，お゙よびある構造属性とそれを実現するほかの構造 属性に関する知識(Fig. 1(c))である。

一般に，目標とする機能を実現する構造は一通りでな い。したがって，ここで提案した知識表現も，目標達成 のための一つの十分条件を表わすものとなる。設計物は, これらの知識を用いて Fig. 1 に示すように基本機能を 頂点とし，表層的な構造上の属性を木端とした木構造で 表現することができる。

この設計物表現において，物理因果法則は連鎖它形成 している。これを物理因果連鎖と呼ぶ。一般に, 目的に 対する手段の選択が数理・物理的に合理的であることを 因果合理性と呼ぶ5)。物理因果連鎖は，目標機能達成に対 する手段として，Fig. 1 で表現された設計物が因果合理

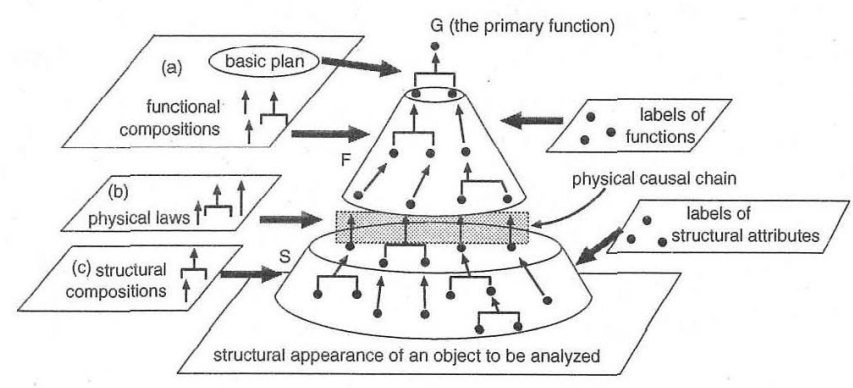

Fig. 1 Multilayered design knowledge
性をもつことを裏付けるものである。

\section{2 決定則の導入}

上述の設計知識は，普遍的関係を表わす含意則として 表現され，論理プログラミング環境下で操作することが 可能である。ところが一般に，対象領域の知識の中で， 含意則の形で厳密にコーディングすることができるのは 一部に過ぎない。したがって，含意則よりも広範囲の対 象領域知識を表現し利用することが可能な知識表現形式 を導入する必要がある。そのような表現形式として，本 研究では Russell らによる決定則について検討する。

彼らは，正当化される (妥当な)類推を可能にするため の知識表現として決定則を提案している ${ }^{2), 3)}$ 。類推は, ソース事例 so において命題 $p$ と $q$ が成立するとき，(類

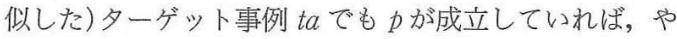
はり $q$ も成立することを結論とする。 $p$ は, so と ta の類 似性を表わすものであり，類似性に基づく学習における 推論結果のもつともらしさ (plausibility)の根拠となる。 しかし，いかに類似点 $p$ が多くて類推結果がもっともら しくても，論理的に正当であるとは限らない。

この類推プロセスの正当化を単一事例の一般化 (SIG : Single Instance Generalization)の正当化問題に帰着さ せると，つぎに示す決定則が導入される。すなわち，事 例のもつ性質 (述語) $p_{1}, p_{2}, \cdots, p_{n}$ が性質 (述語) $q$ 孛決定 する関係 $\left(p_{i}\right.$ 's determine $q$ )を以下のように表わし，

$$
\bigwedge_{i=1}^{n} p_{i}\left(x, y_{i}\right)>q(x, z)
$$

つぎの条件の成立として定義する。

$$
\begin{gathered}
\forall y_{1} \forall y_{2} \cdots \forall y_{n} \forall z\left[(\exists a)\left\{\bigwedge_{i=1}^{n} p_{i}\left(a, y_{i}\right) \wedge q(a, z)\right\}\right. \\
\left.\rightarrow\left\{(\forall x)\left(\bigwedge_{i=1}^{n} p_{i}\left(x, y_{i}\right) \rightarrow q(x, z)\right)\right\}\right]
\end{gathered}
$$

$x$ は $p_{1}, p_{2}, \cdots, p_{n}, q$ に共通に含まれる变数であり，対象 (事例)を表わす。また, $p_{i}$ (あるいは $q$ )だけに含まれる変 数 $y_{i}(z)$ は属性 $p_{i}(q)$ の属性值を表わす(法1).

「構造と材質によって弾性が決まる」という決定関係 を表現する決定則 construction $\left(x, y_{1}\right) \wedge$ material $\left(x, y_{2}\right)$ $>\operatorname{elasticity}(x, z)$ によると, ある要素 $a$ が construction ( $a$, 螺旋), material ( $a$, 鋼鉄), elasticity $(a$, 人)という性質をもつことがわ かれば，同じ構造(螺旋) と材質 (鋼鉄)をもつ 任意の要素も同じ弾性性質(大)をもつことが 保証される。

通常，属性值 $y_{i}$ の値(有限個と仮定) $b_{i 1}$, $b_{i 2}, \cdots$ は互いに排他的であり，対象(事例)の 全体 $\{a\}$ の上分割 (atom) $p_{i j}=\left\{x: p_{i}(x\right.$, $\left.b_{i j}\right)$ が成立 $\}$ を導く.Fig. 2 に示すように，上 記決定則は，性質 $p_{1}, p_{2}, \cdots, p_{n}$ から導かれる 


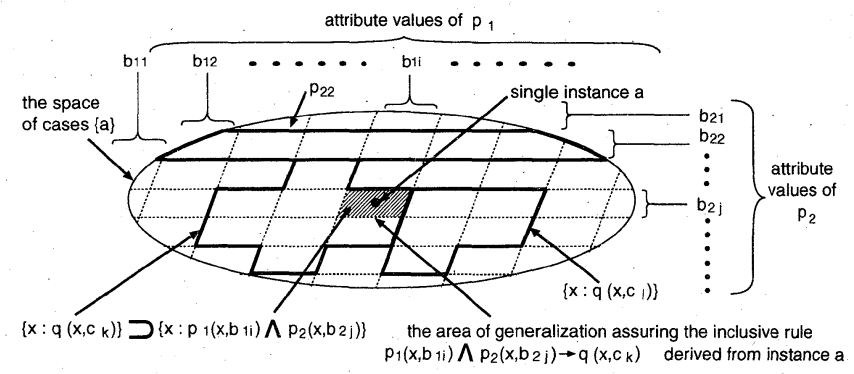

Fig. 2 Interpretation of determination rule

(生成される)分割(図中の矩形)が $q$ から導かれる分割 よりも細かいことを意味している。対象の分割は, 述語 のもたらす情報を意味しており ${ }^{6)}$ ，したがって決定則は $p_{1}, p_{2}, \cdots, p_{n}$ の観測から得られる情報量のほうが $q$ の観 測からのものより大であるという, (個々の観測とは独立 な）メ夕知識を表わしている.

\section{3 設計知識の決定則による表現}

決定則は，含意則として表現することは困難であるが 決定関係として捉えることができる対象領域知識を, 論 理プログラミング環境の下で取り扱うことを可能にする 知識表現形式である. 設計知識を決定則によって表現す る場合, Fig. 1 の設計物表現から考えると, 決定則におけ る被決定項目 $(q)$ は機能または構造属性を表わす一つの 述語, 決定要因 $(p)$ は同じく述語 $p_{i}$ の連言 $\left(\wedge_{i} p_{i}\right)$ から構 成され，決定則はそれらの間の関連を表現することにな る. 代表的なものとして，以下の三つが考えられる。

（1）詳細な分析(説明)を省略する経験則 電流を伝 える機能をもつ構造を考える場合, 設計者はまず材質に 注目する.また，部品を支持するという機能をもたせる ためには, 十分な剛性があることならびに支持する部品 との結合方式に注目する。これは, 設計者が経験から蓄 積している,「どのような構造属性が目的機能達成の成否 を決定するか」という決定関係と考えられる. この決定 関係は，物理因果連鎖による詳細な説明に代わって機能 と構造を連関させる経験的知識である。

また，注目する構造に弾性性質をもたせることを考え たとき，われわれはまず材質と構造に注目する。このよ うな構造属性間の経験的な知識も,「弾性性質は材質と構 造で決定する」という決定関係で捉えることができる.

（2）多くの含意則を生成するメ夕知識 多くの含意 則を明示的にあらかじめ書きつくすことを避け，事例記 述から複数の含意則を生成するためのメ夕知識には, 決

（注 1 ）一般には $x, y_{i}, z$ はそれぞれ変数集合を表わすが， ここでは簡単のため単一変数としている.
定関係で捉えることができるものがある.

物理設計物の要素や機構に関するデータ・情報は, 従来 から十分な整理が行われており，設計活動において利用 価值が高い.これらは，機能・材質・形状などがカタログ 形式で記述されており，これを推論に用いるためには， カタログ項目間の関連性を与える知識が必要である。そ のような関連性の一つに決定関係がある。

（3）複数事例間の類推を可能にする知識 過去に 行った設計事例などの参照は設計における強力な手法で ある.このとき, 論理的に正当(妥当)な類推を行わせる ために,過去の事例のどの機能・構造の参照が必要である かを示す知識は決定則として表現される。

\section{3. 設計知識の獲得}

\section{1 説明に基づく知識獲得}

設計知識は，一つの目的とそれを達成するための十分 条件としての手段の組で表現すると, ホーン節論理で操 作可能になる. そのため, 知識獲得のツールとして EBG (Explanation-Based Generalization) ${ }^{4)}$ を導入すること ができる.

EBG は，解析対象事例(Training Example)が目標概 念(Goal Concept)の正事例であることを領域知識 (Domain Theory)を用いて説明し，その説明の履歴(説 明木)を生成する。説明木生成時に事例記述によって特殊 化された領域知識の各変数は, 説明木内で拘束関係を維 持したまま再び変数化され，同一の解釈が成り立つほか の事例をも包含するように一般化される。この説明木か ら，獲得したい知識がもつ性質を表わす規範(操作性規 範：Operationality Criterion)を満たす表現が選ばれ， 新たな知識として獲得される。

われわれはすすでに EBG を用いた設計知識獲得手法 を提案した ${ }^{7)}$.この手法は, $\mathrm{EBG}$ の目標概念 $(\mathrm{G})$ として解 析対象事例の基本機能, 解析対象事例記述 $(\mathrm{Ta})$ として事 例の表層的な構造が入力されると, 領域知識(D) として 基本プラン・機能・物理因果法則・構造属性に関する知識 


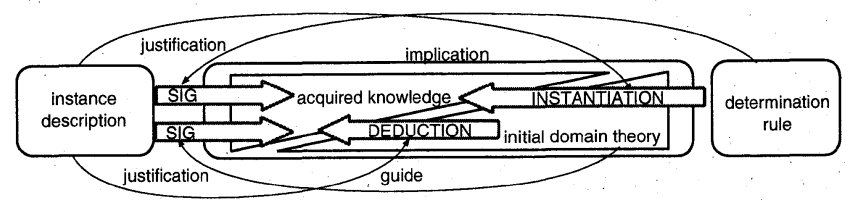

Fig. 3 Two aspects on acquired knowledge

を用いて説明木を生成する. 説明木は, 基本機能の達成 を機能構成および機能と構造の結び付きで表現するもの であり, VEにおける機能系統図とみなすことができる. この機能系統図から，解析対象に依存しない一般的な設 計知識が自動的に獲得される。

EBGによって獲得された知識は, 領域知識を演繹的に 組み合わせ特殊化した結果という側面と，単一事例を一 般化 $(\mathrm{SIG}) し た$ 結果という側面をもつ. 前者に関しては, 演繹推論にようて導くことができる知識をわざわざ知識 ベースに加えることの圥長性から，知識探索効率の低下 が問題となる。したがって, 多くの演繹可能な知識の中 から，探索効率を低下させてまで生成しておくべき価值 のある知識を限定するためのガイドが必要となる，後者 に関しては，一般にはその論理的な正当性(妥当性)が保 証されないことが問題となる. SIGによって生成された 知識に正当性を与える一つの方法として, 健全な推論を 行わせるような背景知識を与えることが考えられる. EBG 手法はこれらの問題を相補的に解決しているとみ なすことができる。すなわち，演繹推論による知識生成 はFig. 3 に示すように実在する事例の記述にガイドさ れるとともに，その SIG は領域知識によって正当化され ている。

\section{$3.2 \mathrm{EBG}$ への決定則の導入}

決定則を $\mathrm{EBG}$ の領域知識として利用することを考え る. 3.1 節で示した視点から $\mathrm{EBG}$ を捉えると, EBG の領 域知識にはつぎの二つの性質が求められる.

性質 1 SIG を正当化する

性質 2 事例記述を加えて設計知識となる

決定則は，どのような対象知識に対していかなる SIG を行うことが正当化されるか, 換言すれば SIGにおいて 一般化することができる $p$ と $q$ 関係の明示的な表現 である．すなわち，決定則は領域知識に求められる性質 1 を満たす。

また，決定則は領域知識に求められる性質 2 を満たす ことも知られている ${ }^{2)} . p \rightarrow q(p$ implies $q)$ ならば $p>q(p$ determines $q$ ) であるが, 逆は成立しない.すなわち, 含 意則 $(p \rightarrow q)$ は決定関係 $(p>q)$ の特殊な場合として考元 ることができ, 決定関係を事例情報で特殊化することで 含意則を獲得することができる.

\section{3 決定則による知識獲得のアルゴリズム}

$\mathrm{EBG}$ と決定則からの知識獲得は,いずれも単一事例記 述を一般化するという側面をもつ，一般化を正当化する 背景知識は，前者では含意則であるのに対して，後者で は決定則という弱い規則である。このため，決定則から の知識獲得は EBGの一般化規則を用いることはでき ず，決定則の定義から導かれるように，「 $\boldsymbol{p}_{1}, \boldsymbol{p}_{2}, \cdots, \boldsymbol{p}_{n}$ と $\boldsymbol{q}$ に共通に含まれる変数だけが一般化される」ことにな る.

本研究では,従来提案されている EBG エンジン ${ }^{8)}$ を拡 張し, 説明木生成, 標準的な事例一般化，ならびに上述 の規則に従う一般化を行う推論エンジンを, prolog (SICStus-prolog)を用いて構築した。また，説明木生成 過程を視覚化し，生成途中での証明済みの部分木からの 知識獲得，ならびに生成された説明木の任意の部分木か らの知識獲得を操作者と対話的に行うことが可能な GUI を作成し，これと上述の推論エンジンとをUNIX のプロセス間通信によって結び付けた実験システムを， ワークステーション上に構築している.

以下に，含意則で記述された領域知識とターゲット事 例記述では説明できない命題 $q$ が説明木に現れたため に，ターゲット事例の説明が中断した場合に，決定則を 用いるときの推論エンジンの動作を示す.

1. 利用可能な決定則 $(p(X, Y)>q(X, Z))$ を探 す(注2).

2. 決定則の $p$ と $q$ ののおのを領域知識ならびに 事例記述を用いて証明する。このとき，決定則は事 例記述に特化される $(p(x, y)>q(x, z))$.

3.これを，先に示した決定則の一般化規則に従って 一般化し, 新たな領域知識 $(p(X, y) \rightarrow q(X, z))$ とし て登録する。

4.この領域知識を用いて，いったん中断されていた ターダット事例の説明を再開する。

\section{4 決定則の利用形態}

説明木生成に決定則 $p>q$ を利用する形態について考 察する. 標準的な EBGにおける説明木は，目標概念を表 わす述語 $G$ を頂点として, 領域知識 $D$ に含まれる含意

（注 2 ） 以降, prolog の表記法に合わせて大文字で表わす引 数は変数, 小文字は個体定数を表わす。 
則を用いてその十分条件を探索し，Dおよび解析対象事 例(ターゲット事例：ta) を記述した述語 $T a$ とマッチし て終端する。すなわち, $D, T a$ を用いた $G$ の証明の履歴 が説明木であるといえる。

この証明に決定則 $p>q$ を朋いる場合, 標準的な $\mathrm{EBG}$ との違いは，qに対する陽な証明が必要なことおおび D, Ta だけでなく参考事例(ソース事例：so)を記述し た述語 So も証明に利用可能であること，の 2 点である。 ここで, 決定則を説明木生成に利用する形態を, $q$ の証明 方法によって分類する。qの証明に利用することができ る $D, T a$, So および G の四つを組み合せると Fig. 4 に 示すように $\left(2^{4}-1=\right) 15$ 通りの証明方法が考えられる。

説明木中の任意のノードは $G$ の十分条件の一つであ る。したがって，ノード $q$ の証明に $G$ を用いることがで きるのは $G \leftrightarrow q$ の場合に限られることになり, 15 の組合 せのうち $G$ を含む 8 通りは一つに集約される。これを以 下では形態a と呼ぶ。

また， Dと Ta(またはその片方)から $q$ が証明可能な 場合 (形態 $\mathrm{b}$ と呼ぶ), 標準的な $\mathrm{EBG} て ゙$ 説明木が生成さ れることになり,So を利用する必要はない。したがって, $T a$ と 0 がともに含まれる組合せ,すなわち形態 $\mathrm{a} に$ 分 類された証明方法の内の二つと, 残りの七つの証明方法 の内の二つ(Fig. 4 に斜線で示す) は排除される。

15 通りの組合せの中で形態 $\mathrm{a}, \mathrm{b}$ に分類された残りの 二つは, $D$ と参考事例記述 $S o$ (または So だけ)から $q$ が 証明される場合である。これを形態 $\mathbf{c}$ と呼ぶ。以下に, 三つの決定則利用形態 $a, b, c$ それぞれの内容を示す。

[形態 a] $G \leftrightarrow q$ が導かれる場合(Fig.5(a))

$G \leftrightarrow q$ となるとき， $p>q$ を用いて説明木を生成可能で あることが知られている 方法をつぎに示す。 $g, q_{n}, p_{n}(n=1,2)$ を述語, $\mathrm{A}$ は変数, $t a, s o$ はそれぞれターゲット事例とソース事例を表わ す.

目標概念 $(G) \quad g(A) \leftrightarrow p_{1}(A) \vee q_{1}(A)$

領域知識 $(\mathrm{D}) \quad p_{2}(A)>q_{1}(A), \cdots$

操作性規範 $\quad p_{1}, p_{2}$ に限り操作的である

事例記述 $(\mathrm{Ta}) \neg p_{1}(t a), p_{2}(t a), \cdots$

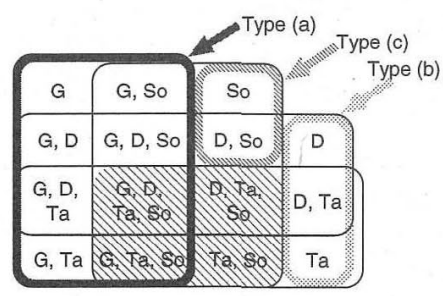

Fig. 4 Various types of $q$ 's proof
説明木は $g(t a)$ の証明履歴として生成される。 $g(t a)$ に対 する $p_{1}$ による証明が失敗するとバックトラックし $g(t a)$ $\leftrightarrow q_{1}(t a)$ となる。 $t a$ は $g$ の正事例であるから $g(t a)$ は真 であり，決定則の右辺が証明されることになる。ここで， 変数 $A$ に $t a$ が代入されたので, 決定則の左辺は $p_{2}(t a)$ となり, 事例記述とマッチして証明される。特化された $q_{1}, p_{2}$ に対し先に示した一般化規則を適用して含意則が 得られるとともに，これを利用して生成された説明木か ら目標概念に対する操作性規範を満たした記述 $p_{2}(A) \rightarrow$ $g(A)$ が得られる。

[形態 b] $D$ と $T a$ (またはとの片方)から $q$ が証明可 能な場合 (Fig. 5(b)).

この場合， DとTa(またはその片方)から $g(t a)$ に対 する説明木が生成されることとなり, 決定則を用いて別 の説明木を生成する必要はない。ただし，つぎの場合 (形 態 b’)に限り決定則の利用が意味をもつ。

[形態 b'] Taの中に $q$ が含まれる場合 (Fig. 5(b'))

$T a$ に操作性規範を満たさない記述が含まれることを 許し, $D$ と $T a$ から $p$ が証明可能ならば, $p>q$ を用いて 操作性規範を満たす記述を得ることができる。

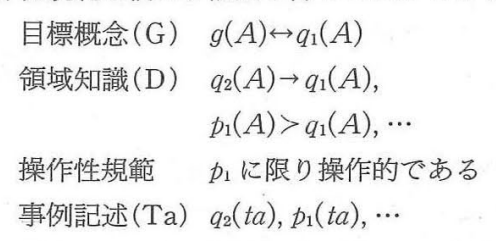
この場合,一つめの領域知識を用いた $g(t a)$ の証明履歴 (標準的な説明木)から得られるのは $q_{2}(A) \rightarrow g(A)$ であ り，これは操作性規範を満たさない。ここで, 決定則の 右辺 $\left(q_{1}\right)$ は証明済であり, 変数 $A$ に $t a$ が代入されてい る。したがって, 決定則の左辺は $p_{1}(t a)$ となり, これが 事例記述によって証明されると, 形態 a と同様に $p_{1}(A)$ $\rightarrow q_{1}(A)$ が得られる。これを用いて, 目標概念に対する操

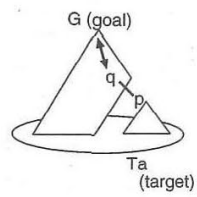

(a)

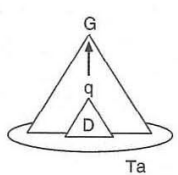

(b)

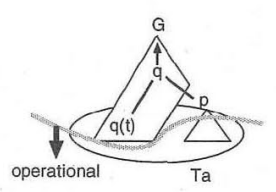

(b')

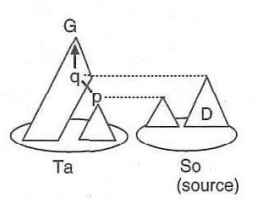

(c)

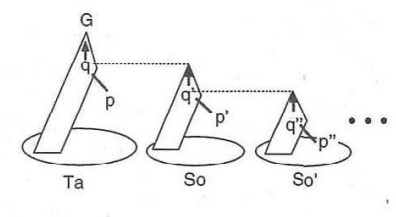

(c')
Fig. 5 Three usage types of determination rules 
作性規範を満たした記述 $p_{1}(A) \rightarrow g(A)$ が得られる。

[形態 c] $D$ と So(または $S o$ だけ)から $q$ が証明可 能な場合 (Fig. 5(c))

この場合をつぎに示す.

目標概念 $(\mathrm{G}) \quad g(A) \leftrightarrow q_{1}(A)$

領域知識 $(\mathrm{D}) \quad p_{1}(A)>q_{1}(A), \cdots$

操作性規範 $\quad p_{1}$ に限り操作的である

事例記述 $\quad p_{1}(t a), q_{1}(s o), p_{1}(s o), \cdots$

この場合, 決定則は So の記述によって証明され, 特化さ れる. 以下形態 $\mathrm{a}, \mathrm{b}$ と同様に, 決定則から得られた $p_{1}(A) \rightarrow q_{1}(A)$ を用いて, 目標概念に対する操作性規範を 満たした記述 $p_{1}(A) \rightarrow g(A)$ が得られる.

[形態 c'] $q$ の証明に複数の参考事例 $\left(S o, S o^{\prime}, \cdots\right)$ が 必要な場合 (Fig. $5\left(c^{\prime}\right)$ )

単一の参考事例 So だけでは証明できない場合, Fig. 5 (c') に示すように, $q$ に対する $S o$ と $D$ による証明の中 に決定則 $p^{\prime}>q^{\prime}$ が使われ， $q^{\prime}$ に対して別の参考事例 $S o^{\prime}$ と $D$ による証明が試みられる(洋3). この形態は決定則を 再㷌的に用いるものであり，形態 b によって終端する. 形態 c は c'の再帰が一段で終端した特別な場合である と捉えることができる。

なお, 上記の形態 $a, b ’$ 説明において, 簡単のために 決定則の左辺は $T a$ と直接マッチすると仮定している が，一般にはその限りではない。すすおち，形態 a にお ける $p_{2}(t a)$ および形態 b'における $p_{1}(t a)$ は節集合 $\{T a$, $D\}$. よって証明されれば良く,さらに, その証明の中で 決定則を用いることも可能である. 同様に, 形態 $\mathrm{c} に お$

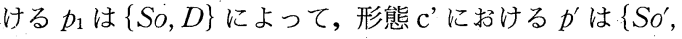
D\}によって証明されれば良い。

\section{4. 物理設計物からの知識獲得}

\section{1 形態 ( c ) による構造属性間の決定関係の利用}

Fig. 6(a)に示す簡単な計測器(バネばかり)を考え る.あらかじめ与えられた計測に対するゴールコンセプ トは, Table 1 中 $G$ に示すように, 機能の組合せとして 定義されている。その表層的な構造特徵による記述を獲 得することを考える. Table 1 において変数 $X, Y, Z$ は(部品などの)構造素, $P, Q, R$ はそれらのもつ構造属 性または物理量を表わす。

領域知識 (Table 1 中 $D)$ には, 機能と構造属性を連関 させる五つの含意則, 二つの決定則, ならびに構造属性 の継承に関する二つの含意則などが含まれている．解析 対象(夕ーゲット)事例 $T a$ の基本機能 $(G)$ は objMaの 質量を $o b j 3 a$ の位置変化として計測することである。す なわち, 説明木は measure (objMa, mass, obj $3 a$, displacement) $G, D, T a$ ならびに So を用いて証明
する履歷として生成される。

（1）式は，説明木中のノード elasticity $(o b j 2 a, W)$ が, $T a$ および $D$ では説明できなくなったときに形態 $(\mathbf{c})$ で用いられる. システムは, Fig. 7 に示すように, 機械要 素の規格表 ${ }^{9)}$ などから得られる参考事例記述 $(S o)$ と, 構 造的に一般的に成立する規則 $(D)$ にって決定則の変数 $X, P_{1}, P_{2}, Q$ をいったん特殊化する. そののち, 決定則 の一般化規則に従って参考にした事例の名前 (jis_g_ 3512) を変数 $X$ に戻し，つぎの知識を生成する.

material $(X$, steel $) \wedge$ construction $(X$, spiral $) \rightarrow$ elasticity $(X$, high $)$

これは, 2.2 節で述べた, 螺旋構造をした鋼鉄部品は一般 に弾性をもつとの知識を表わしている。この決定則を用 いなければ，全ての弾性体に対しておのおの弾性を有す る要因を人間が判断し，領域知識ベースに記載しなけれ ばならない.この含意則を $D$ に加えて説明木の生成が再 開される。

\section{2 形態 $(\mathbf{a})$ による構造属性間の決定関係の利用}

Fig. 6(a)における obj2 $a$ が，力を位置的変化に変え る働き(機能)達成のための部品であることが明らかな場 合を考える. Table 2 に示すように，このときのゴールコ ンセプトの定義は，固定されていないかもしくは弾性が 高いときにそのような機能があると与えられている。 Table 1に示す $D, T a$ を用いて transmit (obj2a, normal_stress, obj2a, displacement) の証明を行うと, $o b j 2 a$ は obj4ak固定されているにもかかわらずゴール コンセプトを満たしていることから，弾性が高いことが 保証され，形態 (a)の形で ( 1 )式が活用される.

\section{3 形態 ( c ) による構造-機能間の決定関係の利用}

Fig. 6 (b ) に示す流速測定器を考える.これは, 測定対 象の流速に関連した撓(たわ) みを棒状の弾性体に発生さ せ，これにより表面に発生する歪みを歪みゲージで電気

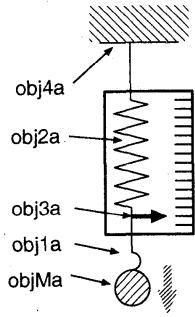

(a)

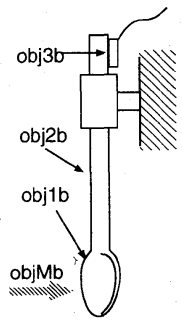

(b)
Fig. 6 Examples of target instance

(注 3 ) 偶発的に $S o^{\prime}$ として $T a$ が用いられ，Ta と Dで $q^{\prime}$ が証明される場合を考えることができる。これは, $q$ の証明に $D, S o, T a$ が用いられる特別な形態に分類される. 
Table 1 An example problem for knowledge acquisition style(a)
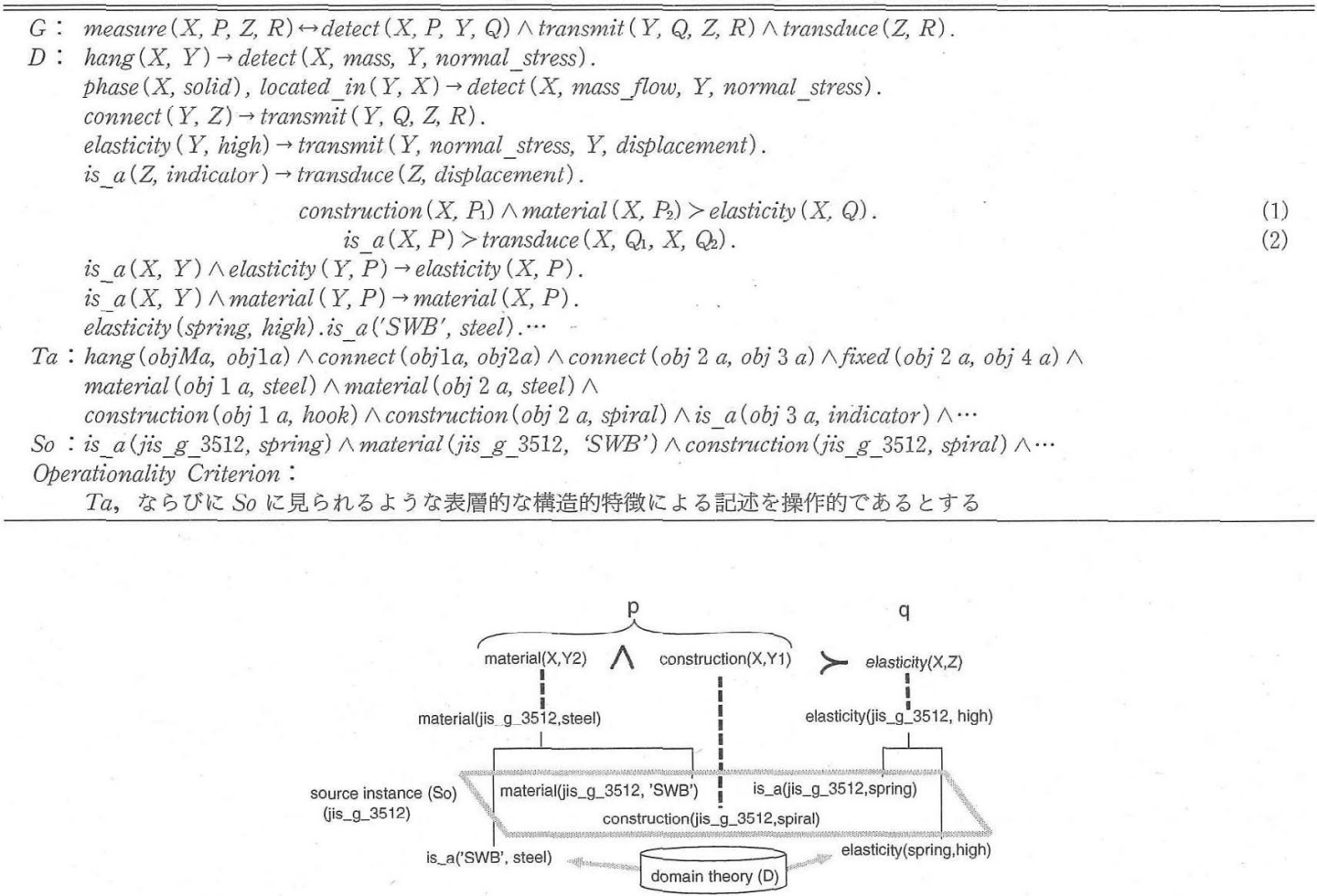

Fig. 7 An example of utilizing determination rules

Table 2 A definition of goal concept "transmit"

$G: \operatorname{transmit}(Y$, normal_stress, $Y$, displacement $) \leftrightarrow \neg$ fixed $(Y$, $) \vee$ elasticity $(Y$, high $)$.

Table 3 An example problem for knowledge acquistion style(b)

$G:$ measure $(X, P, Z, R) \leftrightarrow \operatorname{detect}(X, P, Y, Q) \wedge$ transmit $(Y, Q, Z, R) \wedge \operatorname{transduce}(Z, R, W, S)$.

$T a:$ phase $(o b j M b$, solid $) \wedge$ located_in $($ objld, objMb) $\wedge$ connect $($ obj 1 b, obj $2 b) \wedge$ connect $($ obj $2 b$, obj $3 b) \wedge$ is $a(o b j 3$, strain_gauge $) \wedge \cdots$

So : is_a (transducer 1, strain_gauge $) \wedge$ transduce (transducer 1 , strain, change_in_resistance $) \wedge$ is_a (transducer 2 , voltmeter $) \wedge$ transduce (transducer 2, voltage, displacement $\bar{t}) \wedge \cdots$

抵抗変化倍換するものである。先に示した例と同じく， 機能の形で定義されているゴールコンセプトを表層的な 構造特徵記述に変換する場合を考える。 G, Ta, So は Table 3 のように与えられている。 $D$ と操作性規範法 Table 1 に示したものである。事例の基本機能は objMb の速度を $o b j 3 b$ の電気抵抗変化として測定することて あり, measure (objMb, velocity, obj3b, change_in_ resistance) の証明履歴として説明木が生成される。

(2) 式の右辺は, 構造物 $X$ のもつ物理量 $Q_{1}$ を物理量 $Q_{2}$ に変換する機能を構造物 $X$ がもつことを表わす述 語, 左辺は, 構造物 $X$ がデバイス $P$ であることを表わす
述語とする。この場合，決定則は「変換機能を達成する ことはどのようなデバイスであるかで決まる」ことを表 わしている。

これは，第 2 章で述べたように，物理因果連鎖による 詳細な説明に代わって機能と構造を連関させる経験的知 識を表わしていると考えられる。

(2) 式を含意則に読代えると，任意のデバイスは任 意の物理量变換機能をもつことになり，明らかに過度の 一般化となる。(2)式は, 説明木のノード transduce (obj3b, strain, change_in_resistance) が, $T a$ 拈よびDでは証明できなくなったときに形態( $\mathbf{c}$ ) 
で用いられる.システムは, 決定則をSoに記述されたモ ジュール化された変換デバイスのリストにいったん特殊 化したのち, transducer 1 を変数に戻して, is_a $(A$, strain_gauge $) \rightarrow$

transduce ( $A$, strain, $A$, change_in_resistance) を獲得し，これを利用して説明木が完成される.

\section{4 形態( $\left.\mathbf{b}^{\prime}\right)$ による構造-機能間の決定関係の利用}

Fig. 6(b)の $T a$ において obj3b が歪みを電気抵抗変 化に変換するデバイスであることが明示的に記述されて いる場合, すなわち, Table 3 の Taに transduce (obj3b, strain, obj3b, change_in_resistance) が含まれていると き, 決定則は形態 $\left(\mathbf{b}^{\prime}\right)$ の形で使われる.すなわち, ほかの 事例やデバイスカタログ So を参照することなく決定則 を用いることができる。

\section{5. 設計支援知識の評価}

決定則を事例情報により特化する形で設計知識を獲得 した.これを以後 “決定則からの知識”と呼ぶ. 決定則 からの知識およびあらかじめ含意則として与えられた領 域知識から, 説明木が生成・一般化される。一般化された 説明木の任意の部分木を抽出すると，部分木の末端にあ る機能・構造の連言が，部分木の根にあたる機能・構造に 対する十分条件となっている。これを“説明木からの知 識”と呼ぶ.

ここで,獲得された知識 (決定則からの知識および説明 木からの知識) と, あらかじめ与えられていた知識 (初期 領域知識および決定則)を, 知識利用の合理性, 設計プロ セス進展の効果性の二つの視点 ${ }^{7)}$ から評価する.

\section{1 知識の合理性}

目標とする機能を達成する十分条件としての構造 (設 計解)を, 獲得した設計知識を組み合せる形で生成するプ ロセスを考える，この場合，設計知識の組合せを変える ことによっていくつもの設計解を得ることができるが, それらが全て物理的に実現可能であるとは限らない.こ の実現可能な設計解を導くことが裏付けられていること を, 知識の合理性と呼ぶ。

初期領域知識は，どのような対象の説明にも用いるこ とができるように,一般的に与えられなければならない。 したがって, 初期領域知識を任意に組み合せた知識は, 必ずしも設計に有効な知識である保証はない.

これに対し，2.1節に示したように, 説明木で表現され た解析対象事例が目標機能達成の一つの手段であること の因果合理性は, 物理因果連鎖によって裏付けられてい る.したがって, 説明木の部分木を構成するいくつかの 知識も，その組み合せ方の因果合理性が裏付けられてい る.すなわち, 初期領域知識の任意の組合せの中から,
合理性の高いものが実在事例によって選び出されたもの が説明木からの知識であるといえる。

逆に，これらの知識を利用することができる自由度を 考えると, 説明木からの知識は, 解析対象事例にガイド されたかたちで，領域知識をいくつか組み合せたもので あるため, 解析対象事例に類似の設計に適用範囲が限定 される.

決定則は, 4.3 節で述べたように, 含意則として演繹推 論に用いることはできない。また，決定則はある種過去 の経験によって得られたバイアス的メタ知識であり, 初 期領域知識のような物理法則に基づいた理論的な記述で はない. したがって, 合理性は保証されないが, 多くの 設計局面に適用を試みることができる.

決定則からの知識は，実在事例に用いられている含意 則であるという点で，説明木からの知識と同等である. すなわち，決定関係という本来合理性をもっていない経 験的な知識は, 本研究で提案した手法によって; 合理性 の保証された知識に変換される。

Fig. 8 の横軸は以上の関係を示したものである.

\section{2 知識の効果性}

設計プロセスを，“目的とする基本機能が与えられる と，それを詳細な副機能列に展開し，つぎにおのおのの 副機能を達成することのできる構造属性をもつ物理的実 体を生成するプロセス”であると捉えると，設計知識は この設計プロセスを進展させる度合，すなわち設計知識 の効果性で評価することができる.

説明木から得られた知識は, いくつもの初期領域知識 をチャンク化した知識であるため, その効果性は, 概略 チャンク化される部分木の大きさと対応する.もちろん, プロセスを進展させる度合は,チャンクされる前の個々の 初期領域知識より小さくなることはない. また, 部分木 の大きさは任意に選択可能であるため, 進展の度合の大 きな知識から小さな知識まで, 獲得することができる. 経験則的な側面をもつ決定則は，詳細な分析を省略し 一気にプロセスを進展させるメ夕知識を含む.したがっ て, 初期領域知識と比べると, 要求機能からそれを実現 する構造を発見するプロセスを進める度合が大きい(効

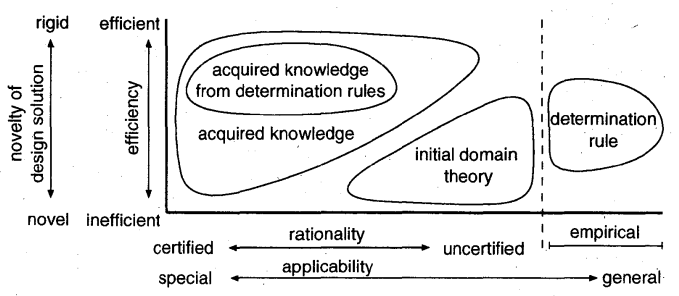

Fig. 8 Assessments of design knowledge 
果的である)反面, 組合せの自由度が小さくなり，新奇な 設計解を得る可能性が小さい,すなわち, 新奇なアイデア を導入する余地の少ない固定的な側面をもつ知識が多い。

決定則からの知識は，効果性に関しては元の決定則と 等しくなる。決定則からの知識を用いた部分を含む形て 部分木を抜きだした場合，すなわち決定則と含意則をと もに利用して獲得された知識は，部分木を構成するため に用いられた個々の知識よりも効果性は高くなる。

Fig. 8 の縦軸によって以上の関係を示す。

\section{6. まと め}

本研究では,目標一手段の連鎖的選択行為の結果として 設計物を捉元，その選択肢を与兄る設計知識として，含 意則と決定則を提案した。これらの知識を $\mathrm{EBG}$ の領域 知識として用いることにより，新たな設計知識を獲得す る方法を提案し，計算機上にシステムを実装し，検討を 行った。

一般に知識獲得手法は，獲得された知識があらかじめ 与えられた知識に比して，知識の利用者のパフォーマン スをどのように向上させるかで評価される10).

本研究では，それぞれの知識には，合理性と利用範囲 の大きさとのトレードオフ，および効果性と新奇性との トレードオフがあることを明らかにした。何れに重点を おくかは，知識利用者の目的や，進行する設計〉ェイズ に依存して判断されるべきものであり，この判断支援を 含め, 獲得知識の効果的活用は今後の検討課題である。

末管ながら，実験システムのコーディングと動作確認 に御協力いただいた三洋電機(株)近藤文剛氏に心より御 礼申し上げます。

\section{参 考 文 献}

1) 玉井正寿：価值分析, 現代経営工学全書, 森北出版 (1978)

2) S. J. Russell : Analogy and Single Instance Generalization, Int. Workshop on Machine Learning, 390/ 397 (1987)

3) T. R. Davies and S. J. Russell : A Logical Approach to Reasoning by Analogy, Proc. of 9 th IJCAI, 264/ 270 (1987)

4) T. M. Mitchell, R. M. Keller and S. T. Kedar-Cabelli : Explanation-Based Generalization: An Unifying View, Machine Learning, 1, 47/80 (1986)

5) 渡辺大助：VE 理論の研究-設計学的アプローチ, 第 17 回 VE 全国大会 VE 研究論文集, 117/124 (1984)

6）本橋信義：現代論理学入門-情報から論理へ-, 岩波書店 (1989)

7）片井, 川上, 椹木, 岩井, 小西: 説明に基づく学習手法を用 いた事例からの操作的設計知識獲得, 計測自動制御学会論 文集, 26-8, 916/923(1990)

8) S. T. Kedar-Cabelli and L. T. McCarty : Explanation-
Based Generalization as Resolution Theorem Proving, Proc. of 4 th Int. Workshop on Machine Learning, 383/ 389(1987)

9）日本規格協会：JISハンドブック機械要素 (1984)

10) R. M. Keller: Defining Operationality for ExplanationBased Learning, Proc. of AAAI 87, 482/487(1987)

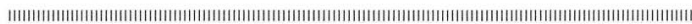

$$
\text { [著 者 紹 介] }
$$

川上浩 司 (正会員)

1987 年, 京都大学工学部精密工学科卒 業. 89 年同大学大学院工学研究科修士課程 修了。同年岡山大学工学部情報工学科助手, 現在に至る (工学博士). 知識情報処理の研 究に従事。人工知能学会の会員。

\section{片井修（正会員）}

1969 年, 京都大学工学部機械工学科卒 業. 同大学大学院博士課程, 助手, 助教授 を経て, 現在教授(精密工学)。その間, 80 ～ 81 年 INRIA (フランス国国立情報処 理・自動化研究所)客員研究員。主にシステ ムの知能化に関する研究に従事(工学博 士).
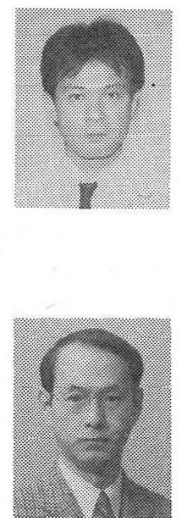

椹 木 哲 夫（正会員）

1983 年, 京都大学工学研究科修士課程, 86 年同博士後期課程修了. 同年同大学工学 部精密工学科助手を経て, 94 年より同助教 授.91〜92 年スタンフォード大学客員研究 員. 知識情報処理, マンマシンシステムの 研究に従事 (工学博士)。

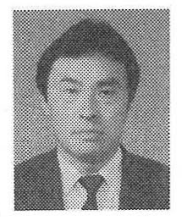

\section{小 西 忠 孝 (正会員)}

1960 年, 京都大学工学部機械工学科卒 業, 65 年同大学大学院博士課程修了 (工学 博士). 同年同人学工学部助教授, 82 年岡山 大学工学部機械工学科教授, 89 年同情報工 学科教授, 現在に至る。設計工学・計測工学 などの研究に従事。日本機械学会の会員.

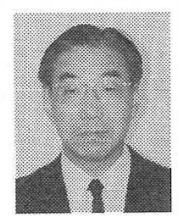

\section{岩 井 壮介(正会員)}

1956 年, 京都大学大学院工学研究科電気 工学専攻修士課程修了. 三菱造船(株) を経 て, 57 年京都大学工学部電子工学科助手, 講師を経て，65 年同精密工学科助教授，74 年教授, 94 年退官。現在, 名城大学理工学 部交通機械学科教授。主に制御工学, シス テム知能化の教育・研究に従事 (工学博士)。

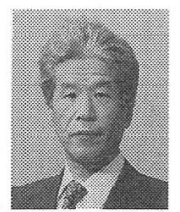

